\title{
Contribution of granulometric fractions in phosphorus distribution in old alluvial soil
}

\begin{abstract}
Phosphorus content and balance in granulometric fractions of old alluvial soil developed from alluvial deposits od Vistula River in middle Poland was studied. The distribution of phosphorus in particular granulometric fractions of the studied soil showed high quantitative variability vertically in the profile. This resulted from the layered structure of the Vistulian old alluvial formation developed throughout the Holocene. The contribution of grain fractions in phosphorus accumulation increased with a decrease in their diameter, and in certain fractions with a decrease in their quantitative state. Eluviation of phosphorus down the soil profile concerned in particular grain fraction $<0.02 \mathrm{~mm}$. Fractions with a larger diameters were not subject to the process. Phosphorus resources calculated from the grain fraction balance in the analysed soil amounted to an average of $1.7 \mathrm{~kg} \cdot \mathrm{m}^{2}$ to a depth of $200 \mathrm{~cm}$.
\end{abstract}

Key words: phosphorus, fractions, granulometric composition, balance, old alluvial soil

\section{INTRODUCTION}

Phosphorus is one of the key elements in living organisms. It serves as an energy carrier in complex organic compounds in plants, animals, and humans. Its resources on Earth are limited, similarly as those of the majority of fossil fuels. According to calculations by geologists, phosphorus resources on Earth amount to 16 billion tonnes (Bondre 2011). Moreover, dispersed deposits with very low concentration of phosphorus are recorded, amounting to 35 billion tonnes. Considering the scale of the current demand, the resources are estimated to last for the next 150 to 175 years.

Considering these data, it is worth studying how to balance phosphorus resources in soils. Polish research regarding the content of phosphorus in soils has been conducted for many years (e.g. Moskal 1963; Brogowski 1966; Brogowski and Okołowicz 1986; Borowiec 1988; Pokojska 1979; Czępińska-Kamińska 1994; Oktaba and Czerwiński 2003; Szara et al. 2005; Sapek 2007). The works, however, do not discuss the balance of phosphorus resources in particular types of soils.

This paper attempts to determine the phosphorus content and balance in particular granulometric fractions. The determination of phosphorus resources in fractions of various soil formations may permit the calculation of its approximate resources in soils exclusively based on the grain size composition, similarly as grain size composition can provide the basis for the calculation of certain physical properties of soils (Brogowski 1990).

\section{MATERIALS AND METHODS}

Endoeutric Cambisol was sampled at the outskirts of the Kampinoska Forest in the vicinity of Kazun Polski village on the old terrace of the Vistula River. The analysed soil in the oxbow lake was composed of layered sediments of the Vistula River, probably from the period of late Pleistocene (particularly the deeper layers).

The soil was separated into granulometric fractions in 5 litre glass bottles after boiling without chemical peptization in order not to modify the chemical composition of fractions. After boiling, the soil was stirred with a rotary stirrer, and transferred to the bottles. The clay fraction was fully separated by means of multiple repetitions of the boiling and stirring process. Fractions with a larger diameter were separated with no further boiling. They were only stirred with a rotary stirrer for approximately a dozen minutes. Water after the deposition of the separated fraction was siphoned off, and used for further separation of fractions. Grains with a diameter of $1.0-0.1 \mathrm{~mm}$ were dried and sieved.

The bulk density of particular granulometric fractions was determined by bulk method in four repetitions. The density was used for the calculation of phosphorus balance in the fractions. 
The soil reaction was determined potentiometrically in $\mathrm{H}_{2} \mathrm{O}$ and $1 \mathrm{~mol} \cdot \mathrm{dm}^{3} \mathrm{KCl}$. The organic carbon was analysed by means of an automatic carbon analyser by Shimadzu TOC $5000 \mathrm{~A}$, and phosphorus by molibdenian method in which p-methylaminophenol sulphate (metol) was used for reduction instead of tin chloride. The method eliminates the potential presence of silica in the solution, giving the same colour as phosphorus. Moreover, the colour of the phosphate solution caused by this method is permanent, and is maintained even for several months (Brogowski 1966).

\section{RESULTS}

The content of phosphorus in particular granulometric fractions (Table 1) of the analysed soil increased with a decrease in their diameter (Table 2).

Fraction with a diameter $<0.002 \mathrm{~mm}$ constituted an average of $15.5 \%$ of whole soil in the uppermost part of the profile composed of old alluvial formations to a depth of $150 \mathrm{~cm}$. Below, to a depth of $200 \mathrm{~cm}$ of whole soil constituting alluvial sediments, its contribution amounted to only $4.1 \%$ (Table 1 ). The content of phosphorus in the fraction $<0.002$ mm evidently corresponds with the character of old alluvial sediments
(Table 1 and 2). In the uppermost part of the profile, to a depth of $70 \mathrm{~cm}$, the fraction is of $50 \%$ poorer in phosphorus than the same fraction from horizons at a depth of $70-150 \mathrm{~cm}$, and by as much as $142 \%$ in comparison to horizons below $150 \mathrm{~cm}$. This suggests increasing content of phosphorus compounds in whole soil with a decrease of the content of fraction (Table 1,2 , and 4). In horizons to a depth of $70 \mathrm{~cm}$, the fraction is depleted in phosphorus compounds most likely as a result of the leaching process.

Fraction $<0.002 \mathrm{~mm}$ accounts for the accumulation of an average of $43.6 \%$ of total phosphorus occurring in the soil in the analysed profile. The values in particular genetic horizons vary considerable from $29.6 \%$ in A horizon to $54.7 \%$ in the deepest horizons underlying the old alluvial formation (Table 3). Based on the calculation of phosphorus balance in the profile, the fraction $<0.002 \mathrm{~mm}$ accumulates $1.08 \mathrm{~kg}$ of this element in the analysed soil with an area of $1 \mathrm{~m}^{2}$ to a depth of $200 \mathrm{~cm}$.

Fraction with a diameter of $0.005-0.002 \mathrm{~mm}$ reached an inconsiderable quantitative contribution in the whole soil, averaging $2.3 \%$ in the profile, varying from $0.6 \%$ in the deepest horizon to $4.1 \%$ in the uppermost part of the profile (Table 1). In contrast to fraction $<0.002 \mathrm{~mm}$, the fraction $0.005-0.002 \mathrm{~mm}$ showed

TABLE 1. Texture of soil, its $\mathrm{pH}$, and content of humus.

\begin{tabular}{|c|c|c|c|c|c|c|c|c|c|c|c|c|}
\hline \multirow{2}{*}{$\begin{array}{l}\text { Depth } \\
\text { (cm) }\end{array}$} & \multirow{2}{*}{$\begin{array}{l}\text { Genetic } \\
\text { horizons }\end{array}$} & \multicolumn{8}{|c|}{ Percentage of fraction, grain size in $\mathrm{mm}$} & \multicolumn{2}{|l|}{$\mathrm{pH}$} & \multirow{2}{*}{$\begin{array}{l}\text { Content } \\
\text { of humus }\end{array}$} \\
\hline & & $1.0-0.25^{1}$ & $0.25-0.1$ & $0.1-0.05$ & $0.05-0.02$ & $0.02-0.01$ & $0.01-0.005$ & $0.005-0.002$ & $<0.002$ & $\mathrm{H}_{2} \mathrm{O}$ & $\mathrm{KCl}$ & \\
\hline $0-30$ & Ap & 8.2 & 33.2 & 13.2 & 17.9 & 6.7 & 4.3 & 3.5 & 13.0 & 5.0 & 4.0 & 1.20 \\
\hline $30-50$ & $\mathrm{ABw}$ & 7.5 & 34.9 & 13.3 & 18.9 & 6.5 & 3.0 & 3.5 & 12.4 & 5.4 & 4.1 & 0.48 \\
\hline $50-70$ & $\mathrm{Bw}$ & 4.2 & 27.7 & 13.0 & 15.6 & 6.2 & 3.4 & 4.1 & 25.8 & 5.6 & 4.1 & 0.33 \\
\hline $70-90$ & $\mathrm{C}$ & 1.2 & 30.6 & 34.8 & 11.6 & 2.1 & 2.3 & 1.6 & 15.8 & 5.7 & 4.2 & 0.34 \\
\hline $90-120$ & $2 \mathrm{C}$ & 2.9 & 48.6 & 14.6 & 14.4 & 2.8 & 1.7 & 1.4 & 13.6 & 5.7 & 4.2 & 0.21 \\
\hline $120-150$ & $3 \mathrm{C}$ & 5.3 & 40.0 & 16.3 & 18.4 & 3.0 & 1.9 & 2.4 & 12.7 & 5.6 & 4.3 & 0.16 \\
\hline $150-175$ & 4D & 20.5 & 46.4 & 11.0 & 6.7 & 10.0 & 0.6 & 1.0 & 3.8 & 6.4 & 5.5 & 0.05 \\
\hline $175-200$ & $5 \mathrm{D}$ & 26.3 & 52.7 & 10.2 & 4.6 & 0.8 & 0.4 & 0.6 & 4.4 & 6.9 & 6.1 & 0.03 \\
\hline Average & & 9.5 & 39.3 & 15.7 & 13.5 & 4.8 & 2.2 & 2.3 & 12.7 & - & - & \\
\hline
\end{tabular}

${ }^{1}$ Grains with a diameter of $1-0.5 \mathrm{~mm}$ occurred in the soil only in trace amounts, below $1 \%$.

TABLE 2. Total content of phosphorus $\left(\mathrm{H}_{2} \mathrm{PO}_{4}\right)$ in fractions in mg per $100 \mathrm{~g}$

\begin{tabular}{|c|c|c|c|c|c|c|c|c|c|c|}
\hline \multirow{2}{*}{$\begin{array}{l}\text { Depth } \\
\text { (cm) }\end{array}$} & \multirow{2}{*}{$\begin{array}{l}\text { Genetic } \\
\text { horizons }\end{array}$} & \multicolumn{8}{|c|}{ Content of phosphorus in mg per $100 \mathrm{~g}$; grain size in mm } & \multirow{2}{*}{$\begin{array}{l}\text { Average for } \\
\text { - the genetic } \\
\text { horizons }\end{array}$} \\
\hline & & $1.0-0.25$ & $0.25-0.1$ & $0.1-0.05$ & $0.05-0.02$ & $0.02-0.01$ & $0.01-0.005$ & $0.005-0.002$ & $<0.002$ & \\
\hline $5-30$ & Ap & 17.5 & 20.0 & 27.5 & 32.5 & 72.5 & 117.5 & 290.0 & 242.5 & 70.0 \\
\hline $30-50$ & $\mathrm{ABw}$ & 7.5 & 17.5 & 22.7 & 30.0 & 45.0 & 80.0 & 140.0 & 275.0 & 59.5 \\
\hline $50-70$ & Bw & 15.0 & 17.5 & 20.0 & 25.0 & 40.0 & 90.0 & 132.0 & 277.5 & 94.5 \\
\hline $70-90$ & $\mathrm{C}$ & 18.4 & 20.0 & 20.0 & 24.4 & 70.0 & 145.2 & 275.3 & 345.0 & 79.8 \\
\hline $90-120$ & $2 \mathrm{C}$ & 16.1 & 12.5 & 16.5 & 25.0 & 70.6 & 148.5 & 218.4 & 408.0 & 75.6 \\
\hline $120-150$ & $3 \mathrm{C}$ & 17.5 & 12.7 & 20.0 & 30.0 & 87.5 & 190.0 & 280.0 & 425.0 & 79.3 \\
\hline $150-175$ & 4D & 5.0 & 7.5 & 35.0 & 62.5 & 82.1 & 121.4 & 232.5 & 660.0 & 46.7 \\
\hline $175-200$ & $5 \mathrm{D}$ & 8.5 & 5.0 & 20.0 & 55.0 & 116.5 & 162.5 & 215.6 & 645.0 & 40.7 \\
\hline Total & & 105.5 & 112.7 & 181.7 & 284.4 & 584.2 & 1055.1 & 1783.8 & 3278.0 & 546.1 \\
\hline Average & & 13.2 & 14.1 & 22.7 & 35.6 & 73.0 & 131.9 & 223.0 & 409.8 & 68.3 \\
\hline
\end{tabular}




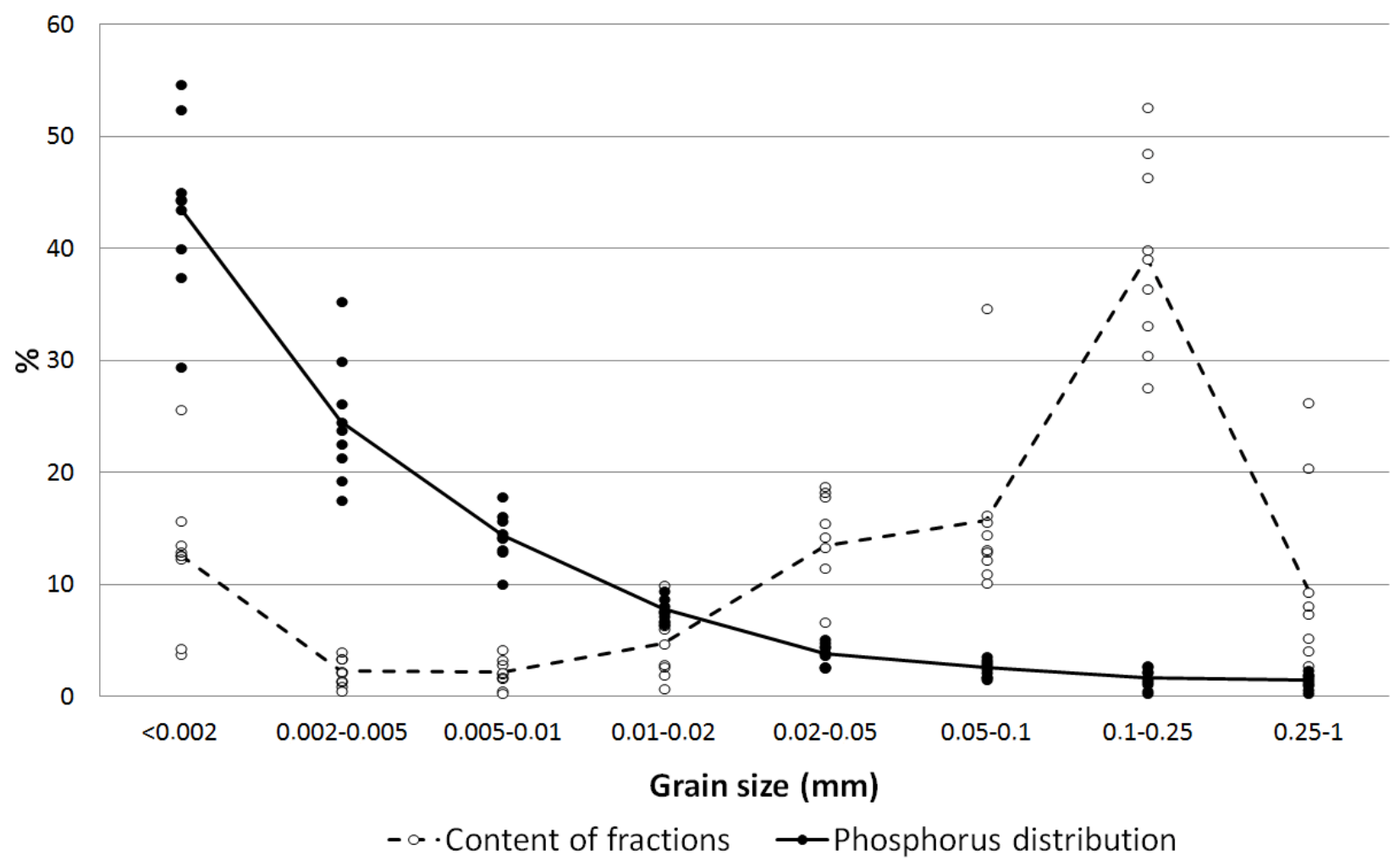

FIGURE. Per cent content of grain fractions, and phosphorus distribution in the fractions

a relatively even content of phosphorus in particular genetic horizons of the soil profile (Table 2 and Figure). The contribution of the fraction in the accumulation of total phosphorus in the analysed soil averaged $24.6 \%$, varying in particular horizons from $17.6 \%$ to $35.4 \%$. The discussed fraction is poorer in phosphorus in comparison to fraction $<0.002 \mathrm{~mm}$ by an average of $45.6 \%$. Therefore, a considerable difference in the content of phosphorus is observed between grains with similar dimensions (Table 2 and 3). According to the balance, low content of the $0.005-0.002 \mathrm{~mm}$ fraction (Table 1) accounts for $94.3 \mathrm{~g} \mathrm{H}_{2} \mathrm{PO}_{4}$ in the profile with an area of $1 \mathrm{~m}^{2}$ to a depth of $200 \mathrm{~cm}$, varying in particular horizons and layers of alluvial sediments from 2.4 to $25.3 \mathrm{~g} \cdot \mathrm{m}^{-2}$ (Table 5).

Fraction with a diameter of $0.005-0.01 \mathrm{~mm}$ reached an inconsiderable contribution in the whole soil, similarly as the fraction discussed above. Its mean content in the soil amounted to $2.2 \%$, with values varying in particular genetic horizons of the soil profile from $0.4 \%$ in the deepest horizon to $4.3 \%$ in the A horizon (Table 1). The discussed fraction is poorer in phosphorus than the fraction with a diameter $0.005-$ $0.002 \mathrm{~mm}$ by an average of $40.8 \%$, and than fraction $<0.002 \mathrm{~mm}$ by $67.8 \%$. The distribution of phosphorus in this fraction in the soil profile is variable (Table 2). The lowest amount of phosphorus bound to this fraction occurred in the uppermost part of the profile, and the highest in the middle part. The per cent contribution of the fraction in phosphorus accumulation is very even throughout the profile (Table 3 and Figure). This fraction accounted for an average of $14.4 \%$ of total phosphorus accumulated in the analysed soil, with values varying in particular genetic horizons from 10.1 to $17.9 \%$. Due to the low content of the discussed fraction in whole analysed soil (Table 1), only $55.9 \mathrm{~g} \mathrm{P} \cdot \mathrm{m}^{-2}$ on average was accumulated to a depth of $200 \mathrm{~cm}$ (Table 5).

Fraction with a diameter of $0.01-0.02 \mathrm{~mm}$ had an average contribution of $4.8 \%$ in whole soil, varying in the profile from 0.8 to $10.0 \%$ (Table 1 ). In comparison to the clay fraction $(<0.002 \mathrm{~mm})$, this fraction is poorer in phosphorus compounds by an average of $82.2 \%$. The content of phosphorus in the fraction $0.01-0.02 \mathrm{~mm}$ increased gradually down the soil profile, excluding horizon A(Table 2). The deepest horizon $(175-200 \mathrm{~cm}$ ) with the lowest content of the fraction is the most abundant in phosphorus (Table 1). The per cent contribution of the fraction in phosphorus accumulation is very low, accounting for binding of only $7.8 \%$ on average of total phosphorus in the soil (Table 3 and Figure). The contribution of the fraction in binding phosphorus is similar to its per cent contents in the whole analysed soil (Figure).

A quantitative increase in the fraction $0.01-0.02 \mathrm{~mm}$ in relation to the one discussed above resulted in an 
TABLE 3. Contribution of granulometric fractions in phosphorus accumulation in soil (in \%).

\begin{tabular}{lllllllll}
\hline \multirow{2}{*}{$\begin{array}{l}\text { Depth } \\
(\mathrm{cm})\end{array}$} & $\begin{array}{l}\text { Genetic } \\
\text { horizons }\end{array}$ & \multicolumn{6}{l}{ Grain size in $\mathrm{mm}^{1}$} \\
\cline { 3 - 9 } & & $1.0-0.25$ & $0.1-0.02$ & $0.02-0.01$ & $0.01-0.005$ & $0.005-0.002<0.002$ & $<0.02$ \\
\hline $5-30$ & $\mathrm{Ap}$ & 4.5 & 7.4 & 8.8 & 14.3 & 35.4 & 29.6 & 88.1 \\
$30-50$ & $\mathrm{ABw}$ & 4.0 & 8.6 & 7.3 & 13.0 & 22.7 & 44.4 & 87.4 \\
$50-70$ & $\mathrm{Bw}$ & 5.2 & 7.2 & 6.5 & 14.6 & 21.4 & 45.1 & 87.2 \\
$70-90$ & $\mathrm{C}$ & 2.2 & 4.9 & 7.6 & 15.8 & 30.0 & 37.5 & 90.9 \\
$90-120$ & 2C & 3.2 & 4.5 & 7.7 & 16.2 & 23.9 & 44.5 & 92.3 \\
$120-150$ & 3C & 2.8 & 4.7 & 8.2 & 17.9 & 26.3 & 40.1 & 92.5 \\
$150-175$ & 4D & 1.0 & 8.1 & 6.8 & 10.1 & 19.3 & 54.7 & 90.9 \\
$175-200$ & 5D & 1.1 & 6.1 & 9.5 & 13.2 & 17.6 & 52.5 & 92.8 \\
\hline Average & & 3.2 & 6.4 & 7.8 & 14.4 & 24.6 & 43.6 & 90.4 \\
\hline
\end{tabular}

${ }^{1}$ Total phosphorus (mg per $100 \mathrm{~g}$ ) in genetic horizons in fractions $<1 \mathrm{~mm}=100 \%$.

TABLE 4. Per cent contribution of genetic soil horizons in phosphorus accumulation by particular granulometric fractions. Total phosphorus in a particular fraction in the soil profile at a depth from 0 to $200 \mathrm{~cm}=100 \%$ (see Table 2)

\begin{tabular}{llllllllll}
\hline \multirow{2}{*}{$\begin{array}{l}\text { Depth } \\
(\mathrm{cm})\end{array}$} & $\begin{array}{l}\text { Genetic } \\
\text { horizons }\end{array}$ & \multicolumn{2}{l}{ Grain size in $\mathrm{mm}^{1}$} \\
\cline { 3 - 11 } & $1.0-0.25$ & $0.25-0.1$ & $0.1-0.05$ & $0.05-0.02$ & $0.02-0.01$ & $0.01-0.005$ & $0.005-0.002$ & $<0.002$ \\
\hline $5-30$ & $\mathrm{Ap}$ & 16.6 & 17.7 & 15.1 & 11.4 & 12.4 & 11.1 & 16.3 & 7.4 \\
$30-50$ & $\mathrm{ABw}$ & 7.1 & 15.5 & 12.5 & 10.5 & 7.7 & 7.6 & 7.8 & 8.4 \\
$50-70$ & $\mathrm{Bw}$ & 14.2 & 15.5 & 11.0 & 8.8 & 6.8 & 8.5 & 7.4 & 8.5 \\
$70-90$ & $\mathrm{C}$ & 17.4 & 17.7 & 11.0 & 8.6 & 12.0 & 13.8 & 15.4 & 10.5 \\
$90-120$ & 2C & 15.3 & 11.1 & 9.1 & 8.8 & 12.1 & 14.1 & 12.2 & 12.4 \\
$120-150$ & 3C & 16.6 & 11.3 & 11.0 & 10.5 & 15.0 & 18.0 & 15.7 & 13.0 \\
$150-175$ & 4D & 4.7 & 6.6 & 19.3 & 22.0 & 14.0 & 11.5 & 13.0 & 20.1 \\
$175-200$ & 5D & 8.1 & 4.6 & 11.0 & 19.4 & 20.0 & 15.4 & 12.2 & 19.7 \\
\hline Average & & $100 \%$ & $100 \%$ & $100 \%$ & $100 \%$ & $100 \%$ & $100 \%$ & $100 \%$ & $100 \%$ \\
\hline
\end{tabular}

increase in the amount of the accumulated phosphorus. It amounts to an average of $70.2 \mathrm{~g} \mathrm{P}$ per $1 \mathrm{~m}^{2}$ to a depth of $200 \mathrm{~cm}$ (Table 5). The variations in the value in the profile are proportional to the content of granulometric fractions (Table 1 and 5).

Fractions with a diameter of $0.02-0.1 \mathrm{~mm}$ reached a considerable contribution in whole soil, averaging $21.2 \%$ in the profile (Table 1 ). The fractions are poorer in phosphorus by $93.0 \%$ than the richest fraction $(<0.002 \mathrm{~mm})$. Therefore, their contribution in the total content of phosphorus amounted to approximately $7.0 \%$ (Tables 2 and 3, Figure). The distribution of phosphorus in the fractions in the soil profile is relatively even with the exception of the fraction with a diameter of $0.05-0.02 \mathrm{~mm}$, largely enriched in phosphorus in the deepest horizons (Table 2). Fractions $0.02-0.01 \mathrm{~mm}$ combined accumulated an average of $212.6 \mathrm{~g} \mathrm{P}$ per $1 \mathrm{~m}^{2}$ in the analysed soil to a depth of $200 \mathrm{~cm}$ (Table 5). This relatively high amount of accumulated phosphorus results from a high contribution of the fractions in the soil mass (Table 1 and 3).

Fraction with a diameter of $0.1-1.0 \mathrm{~mm}$ constituted almost half of whole soil, and amounted to a total of $48.7 \%$ (Table 1). The fraction contained low amounts of phosphorus amounting to an average of $3.5 \%$ of the total resources in the analysed soil (Table 2 and 3 , Figure). The fraction binds only $188 \mathrm{~g}$ of phosphorus in the analysed soil per $1 \mathrm{~m}^{2}$ of the profile to a depth of $200 \mathrm{~cm}$ (Table 5).

TABLE 5. Phosphorus balance in grain fractions of soil in $\mathrm{g} \cdot \mathrm{m}^{-2}$ of genetic horizons

\begin{tabular}{|c|c|c|c|c|c|c|c|c|c|c|}
\hline \multirow{2}{*}{$\begin{array}{l}\text { Depth } \\
(\mathrm{cm})\end{array}$} & \multirow{2}{*}{$\begin{array}{l}\text { Genetic } \\
\text { horizons }\end{array}$} & \multicolumn{9}{|c|}{ Grain size $(\mathrm{mm})$} \\
\hline & & $1.0-0.25$ & $0.25-0.1$ & $0.1-0.05$ & $0.05-0.02$ & $0.02-0.01$ & $0.01-0.005$ & $0.005-0.002$ & $<0.002$ & sum \\
\hline $5-30$ & Ap & 5.0 & 27.4 & 13.3 & 19.9 & 13.6 & 13.3 & 25.2 & 75.7 & 193.4 \\
\hline $30-50$ & $\mathrm{ABw}$ & 1.4 & 20.4 & 8.4 & 16.0 & 7.0 & 5.0 & 9.9 & 76.6 & 144.7 \\
\hline $50-70$ & $\mathrm{Bw}$ & 1.7 & 15.0 & 7.5 & 10.9 & 5.8 & 6.4 & 10.8 & 183.2 & 241.3 \\
\hline $70-90$ & $\mathrm{C}$ & 0.6 & 18.5 & 20.9 & 7.9 & 3.3 & 7.1 & 11.6 & 153.5 & 223.4 \\
\hline $90-120$ & $2 \mathrm{C}$ & 2.1 & 28.8 & 10.4 & 14.4 & 6.5 & 8.2 & 9.2 & 190.4 & 284.4 \\
\hline $120-150$ & $3 \mathrm{C}$ & 4.4 & 24.4 & 14.8 & 23.0 & 8.8 & 12.0 & 19.6 & 213.8 & 320.8 \\
\hline $150-175$ & $4 \mathrm{D}$ & 4.1 & 14.2 & 14.4 & 14.4 & 22.6 & 2.1 & 5.6 & 75.5 & 152.9 \\
\hline $175-200$ & $5 \mathrm{D}$ & 9.3 & 10.7 & 7.6 & 8.8 & 2.6 & 1.8 & 2.4 & 93.5 & 136.7 \\
\hline Total & & 28.6 & 159.4 & 97.3 & 115.3 & 70.2 & 55.9 & 94.3 & 1076.6 & 1697.6 \\
\hline
\end{tabular}




\section{DISCUSSION}

Phosphorus is an element which compounds considerably respond to the soil-forming processes occurring in the soil profile (Pokojska 1979; Czępińska-Kamińska 1994). Therefore, the calculated per cent contribution of genetic horizons of the analysed soil in phosphorus accumulation by particular granulometric fractions clearly identifies those susceptible to the leaching processes, and those resistant to the process (Table 4 and Figure).

Grains with a diameter of $>0.05 \mathrm{~mm}$ show no vertical migration of phosphorus compounds in the profile of the analysed soil. This may result from the fact that grains with such a diameter are not enriched in phosphorus compounds, and their low amounts may occur in the grains in the form of inclusions in mineral grains. Grains with diameters of $<0.05 \mathrm{~mm}$ show evident deficits of phosphorus in the horizons of the analysed soil to a depth of 70, and even $120 \mathrm{~cm}$ (Table 4). At the highest depths, phosphorus is removed from grains with a diameter of $0.05-0.02 \mathrm{~mm}$. The grains $<0.02 \mathrm{~mm}$, including clay fraction $<0.002 \mathrm{~mm}$, show evident deficits of phosphorus to a depth of $70 \mathrm{~cm}$ (Table 4).

Granulometric fractions with a diameter of $0.05-$ $0.002 \mathrm{~mm}$ from the uppermost horizon to a depth of $30 \mathrm{~cm}$ are enriched in phosphorus in relation to the fractions from horizons $30-70 \mathrm{~cm}$. This may result from the presence in the fractions of organic compounds containing phosphorus but still not fully humified. Therefore, the leaching processes are not capable of removing phosphorus from organic compounds (Table 4). Clay fraction $<0.002 \mathrm{~mm}$ shows evident depletion in phosphorus compounds in horizon Ap. In this fraction, organic compounds are usually fully humified, and phosphates could be subject to leaching during the process (Table 4), together with fulvic acids soluble in water.

\section{CONCLUSIONS}

1. The content of phosphorus in granulometric fractions increased more or less evenly with a decrease in their diameter.

2. The accumulation of phosphorus in certain cases increased in the same group of fractions with a decrease in its quantitative state in the soil mass.

3. The main phosphorus resources in the analysed soil are accumulated in granulometric fractions with a diameter of $<0.02 \mathrm{~mm}$. They accumulate an average of $90.4 \%$ of total phosphorus occurring in the soil. The values in particular horizons and layers vary from 87.2 to $92.8 \%$.
4. The distribution of phosphorus among particular granulometric fractions in genetic horizons of the soil profile may constitute an indicator of soil-forming processes.

5. Leaching processes in the analysed soil concerned all fractions with a diameter of $<0.02 \mathrm{~mm}$, and particularly the fraction with a diameter of $<0.002$ $\mathrm{mm}$.

6. Based on the calculated phosphorus balance in the analysed soil, the resources of this element per $1 \mathrm{~m}^{2}$ to a depth of $200 \mathrm{~cm}$ amount to approximately $1.7 \mathrm{~kg}$, and to a depth of $1 \mathrm{~m}-0.8 \mathrm{~kg}$.

\section{REFERENCES}

Bondre N., 2011. Phosphorus: How much is enough. Global Change Magazine. International Geosphere-Biosphere Program, Stockholm, 76(6): 14-17.

Borowiec J., 1988. Rozmieszczenie związków fosforu w poszczególnych frakcjach mechanicznych utworów glebowych (Distribution of phosphorus compounds in particular mechanical fractions of soil formations). Prace Naukowe AE we Wrocławiu, Chemia 426: 44-52. (in Polish)

Brogowski Z., 1966. Metodyka oznaczania mineralnego i organicznego fosforu w glebie (Methodology for the determination of mineral and organic phosphorus in the soil). Roczniki Gleboznawcze - Soil Science Annual, 16(1): 193-208. (in Polish)

Brogowski Z., 1990. Próba obliczenia niektórych właściwości fizycznych gleb na podstawie analizy ziarnowej (Attempt to calculate certain physical properties of soils based on granulometric analysis). Roczniki Gleboznawcze - Soil Science Annual, 31(3-4): 17-28. (in Polish)

Brogowski Z., Okołowicz M., 1986. Rozmieszczenie związków fosforu w glebie kopalnej wytworzonej z holoceńskich piasków wydmowych (Distribution of phosphorus compounds in fossil soil developed from Holocene dune sands). Wydawnictwa SGGW: 179-187. (in Polish)

Czępińska-Kamińska D., 1994. Wpływ procesu bielicowania na profilowe rozmieszczenie mineralnych związków fosforu (Effect of the podzolization process on the profile distribution of mineral phosphorus compounds). Roczniki Gleboznawcze Soil Science Annual, 44(suppl.): 63-70. (in Polish)

Moskal S., 1963. Izotopowe metody oznaczania łatwo dostępnych dla roślin fosforanów glebowych (Isotopic methods for determination of the available for plants soil phosphates). Roczniki Gleboznawcze - Soil Science Annual, 13(suppl.): 249-253. (in Polish)

Oktaba L., Czerwiński Z., 2003. Ogólna zawartość fosforu i jego formy w glebach murszowych i murszowatych z poziomami rudy darniowej (The content of phosphorus and its different compounds in muck and mucky soils with bog iron horizon). Roczniki Gleboznawcze - Soil Science Annual, 54(4): 6775. (in Polish)

Pokojska U., 1979. Geochemical studies of podzolization. Part 3. Phosphorus in podzolization. Roczniki Gleboznawcze Soil Science Annual, 33(2): 153-160. 
Sapek A., 2007. Przyczyny zwiększania się zasobów fosforu w glebach polskich (Reasons for the increasing of phosphorus pool in Poland's soils). Roczniki Gleboznawcze - Soil Science Annual, 58(3/4): 110-118. (in Polish)
Szara E., Mercik S., Sosulski T., 2005. Formy fosforu w doświadczeniach wieloletnich (Forms of phosphorus in multiannual experiments). Fragmenta Agronomica, 85: 298-309. (in Polish)

Received: December 15, 2014

Accepted: February 18, 2015

\section{Udzial frakcji granulometrycznych w rozmieszczeniu fosforu w glebie staroaluwialnej}

Streszczenie: Badano zawartość oraz obliczono bilans fosforu we frakcjach granulometrycznych wydzielonych z gleby staroaluwialnej, wytworzonej z osadów rzecznych Wisły w środkowej Polsce. Zawartość fosforu w poszczególnych frakcjach granulometrycznych badanej gleby wykazuje duże zróżnicowanie ilościowe w pionie profilu. Wynika to z warstwowej budowy utworu staroaluwialnego Wisły powstałego na przestrzeni całego okresu holoceńskiego. Udział frakcji w magazynowaniu fosforu wzrasta wraz ze zmniejszaniem się ich średnicy oraz w niektórych frakcjach wraz ze zmniejszaniem się ich stanu ilościowego. Wymywanie fosforu w głąb profilu glebowego dotyczy głównie frakcji $<0,02 \mathrm{~mm}$. Frakcje o większej średnicy nie są objęte tym procesem. Zasoby fosforu obliczone z bilansu frakcji w badanej glebie wynoszą średnio $1,7 \mathrm{~kg}$ na $\mathrm{m}^{2}$ do głębokości $200 \mathrm{~cm}$.

Słowa kluczowe: fosfor, frakcje, skład granulometryczny, bilans, gleba staroaluwialna 